\title{
EFEKTIVITAS ABATE DAN EKSTRAK DAUN SIRIH (Piper betle) DALAM MEMATIKAN LARVA Aedes aegypti L INSTAR III
}

\author{
Triana Oktaviani ${ }^{1}$, Zairinayati ${ }^{2}$ \\ Program Studi DIII Kesehatan Lingkungan, STIKes Muhammadiyah Palembang \\ Email : zairinayati@yahoo.co.id
}

\begin{abstract}
ABSTRAK
Latar Belakang: Aedes aegypti merupakan nyamuk yang dapat berperan sebagai vektor Demam Berdarah Dengue (DBD). Upaya promotif dan preventif menjadi mutlak dilakukan untuk memutus mata rantai penularan dengan membunuh larva nyamuk dengan larvasida alami menggunakan ekstrak daun sirih (Piper betle) sebagai insektisida alami. Tujuan dari penelitian: ini adalah untuk mengetahui perbedaan abate dan ekstrak daun sirih (Piper betle) dalam mematikan larva Aedes aegypti $L$ instar III. Desain penelitian: ini bersifat eksperimen dengan menggunakan rancangan acak lengkap (RAL) yang terdiri dari 3 perlakuan 1 kontrol dan 8 kali pengulangan percobaan. Hasil Penelitian: dapat diketahui bahwa untuk penggunaan ekstrak daun sirih (Piper betle) dengan konsentrasi 5\% dapat mematikan larva sebanyak 8 ekor, sedangkan konsentrasi 10\% tidak dapat mematikan larva (0 larva) dan konsentrasi 15\% dapat mematikan larva sebanyak 17 (85\%) sedangkan untuk penggunaan abate dengan konsentrasi 5\%,10\% dan 15\% dapat mematikan larva sebanyak 160 larva (100\%). Kesimpulan: bahwa abate mempunyai efektifitas lebih tinggi di banding dengan ekstrak daun sirh (Piper betle).
\end{abstract}

Kata Kunci

: Aedes aegypti, Abate, Ekstrak Daun sirih.

\section{ABSTRACT}

Background: Aedes aegypti is a mosquito that can act as a vector of dengue Hemorrhagic Fever (DHF). Promotove and preventive effort are absolutely necessary to break the chain to transmission by killing mosquito larvae with natural larvacides using betel leaf extract (Piper betle) as a natural insecticides. The purposes of this study: this was to determine the differences in abate and betel leaf extract (Piper batle) in kliing Aedes aegypti instar III larvae. Research methods this is an experimental study using a completely randomized design (CRD) consisting of 3 treatments 1 control and 8 repetitions of the experiment. The results: it can be seen that for the use of betel leaf extract(Piper betle) with a concentration cannot kill larvae in $17(85 \%)$ whilke for the use of abate with a concentration of 5\%, 10\% and 15\% can kill larvae of 160 (100\%). Conclusion: that the abate has a higher effectiveness compared to sirih leaf extract.

Keyword : Aedes aegypti, abate, betel leaf extract

\section{PENDAHULUAN}

Nyamuk merupakan serangga yang menimbulkan banyak penyakit karena berfungsi sebagai vektor pembawa bibit penyakit. Spesies yang paling populer adalah Aedes aegypti L. Nyamuk Aedes aegypti L ini merupakan vektor penyebab penyakit Demam Berdarah Dengue. (Yunita, dkk,
2009). Aedes aegypti tersebar luas di seluruh Indonesia, nyamuk ini dapat ditemukan di pemukiman penduduk yang padat hingga ke pedesaan yang dekat dengan pelabuhan yang terbawa melalui transportasi yang mengangkut benda-benda yang berisi air hujan yang mengandung larva. Upaya pengendalian telah banyak dilakukan oleh 
pemerintah. Cara untuk mencegah penyakit tersebut adalah mengendalikan vektornya dengan penggunaan larvasida golongan kimiawi, abate (temephos). Larvasida ini sudah digunakan sejak tahun 1976, pada tahun tahun 1980 abate ditetapkan sebagai bahan dalam program pemberantasan massal Aedes aegypti di Indonesia hingga kini abate ini sudah digunakan lebih dari 30 tahun. (Natadisastra dalam Ramayanti 2016)

Bentuk pencegahan yang sudah dilakukan selama ini menggunakan bubuk abate sebagai upaya pemberantasan vektor penyakit Demam Berdarah Dengue (DBD), namun dibalik manfaat penggunaan abate terdapat hasil penelitian yang menyatakan bahwa penggunaan insektisida ataupun abate yang berulang dapat menambah risiko kontaminasi residu pestisida dalam air, terutama air minum (Kardinan, 2007), kemudian didapatkan juga bahwa telah terjadi resistensi larva Aedes aegypti terhadap temephos di Argentina sehingga menunjukkan bahwa perlu dilakukan upaya pemberantasan yang ramah lingkungan dan memiliki nilai efektivitas yang tinggi. (Lidia K, 2008)

Daun sirih (Piper betle L) merupakan salah bahan alami yang bisa dimanfaat sebagai bahan insektisida ekstrak daun sirih mengandung minyak atsiri dan senyawa alkaloid. (Ridha, 2015) Senyawa-senyawa seperti sianida, saponin, tanin, flafonoid, steroid, alkanoid dan minyak atsiri diduga dapat berfungsi sebagai insektisida.
Beberapa penelitian menguatkan bahwa pemanfaatan tanaman sirih memiliki daya racun serangga (Piper betle atau Charica betle) dan jentik sebagaimana hasil penelitian menunjukkan bahwa rata-rata kematian larva A. aegypti menggunakan ekstrak daun sirih dengan dosis 1 gr/l kematian larva yaitu 17,6 (70,6\%). (Prastha, 2015). Sejalan dengan penelitian lain yang menunjukkan menunjukan bahwa ekstrak daun sirih dan daun bengkuang pada dosis 2,0 $\mathrm{mg} / \mathrm{l}$ selama 24 jam mampu mematikan larva Aedes aegypti sebesar 96,6 \%, sedangkan abate dengan dosis 2,0 $\mathrm{mg} / \mathrm{l}$ selama 24 jam mampu mematikan larva Aedes aegypti sebesar $70 \%$.

Berdasarkan latar belakang diatas tujuan penelitian ini adalah untuk mengetahui perbedaan abate dan ekstrak daun sirih (Piper betle) dalam mematikan larva Aedes aegypti $L$ instar III.

\section{METODE PENELITIAN}

Penelitian ini bersifat eksperimen menggunakan rancangan acak lengkap (RAL) yang terdiri dari 3 perlakuan 8 kali pengulangan dan kontrol. Subyek penelitian ini adalah larva Aedes Aegypti instar III. Dosis abate dan ekstrak daun sirih masingmasing $(5,10,15 \mathrm{ppm} / 100 \mathrm{ml}$ air) dan kontrol. Langkah kerja penelitian sebagai berikut:

a. Tahap Pembuatan Ekstrak Daun Sirih (Piper betle)

Daun sirih 500 gr dicuci, dijemur kemudian digiling menjadi serbuk hingga diperoleh sekitar 100 gram. Serbuk 
dimasukkan ke dalam becker glass kemudian ditambahkan alkohol 95\% sebanyak 1 liter sampai terendam, diaduk dan didiamkan selama 24 jam. Saring dan didestilasi (panaskan) sehingga didapatkan 1 liter hasil destilasi penguapan, kemudian diamkan selama 2 hari. Ekstrak untuk digunakan.

b. Tahap Pengujian Efektivitas Abate (temephos)

Larva instar III masing-masing berisi 20 larva, ditambahkan abate (5-10-15 ppm/100 ml air). Pengamatan dilakukan untuk setiap perlakuan dan dilakukan perhitungan larva yang mati setiap 45 menit. Larva yang mati merupakan larva yang mengambang pada wadah dan sudah tidak menunjukkan tanda-tanda bergerak/hidup.

c. Tahap Pengujian Ekstrak Daun Sirih (Piper betle)

Sama halnya dengan pengujian abate larva instar III masing-masing berisi 20 larva kemudian masukkan ke dalam wadah ditambahkan ekstrak daun sirih (Piper betle) 5-10-15 ppm/100 ml air) lakukan pengamatan dan perhitungan larva yang mati setiap 45 menit.

Pengolahan dan Analisa Data disajikan dalam distribusi data univariat untuk melihat distribusi frekuensi abate dan esktrak daun sirih terhadap kematian larva Aedes aegypti $L$ instar III.

\section{HASIL PENELITIAN}

1. Analisa Univariat

Tabel. 1

Distribusi Frekuensi Jumlah Kematian Larva Aedes aegypti Instar III dengan Ekstrak Daun Sirih

\begin{tabular}{clllllllllllll} 
& & \multicolumn{1}{c}{ Kematian Larva setia Pengulangan } & Rata-rata & \\
No & Konsentrasi & 1 & 2 & 3 & 4 & 5 & 6 & 7 & 8 & & Kematian & $\%$ \\
1 & $5 \%$ & 2 & 0 & 0 & 0 & 0 & 0 & 5 & 1 & 20 & 1 & 5 \\
2 & $10 \%$ & 0 & 0 & 0 & 0 & 0 & 0 & 0 & 0 & 20 & 0 & 0 \\
3 & $15 \%$ & 0 & 0 & 1 & 16 & 0 & 0 & 0 & 0 & 20 & 2,13 & 5,6
\end{tabular}

Pada tabel. 1 menunjukkan bahwa pada dosis $5 \%$ dengan 8 kali pengulangan, dengan waktu kontak selama 45 menit jumlah larva nyamuk yang mati didapatkan hasil pada perlakuan 1 sebanyak 2 larva, pada perlakuan 7 sebanyak 5 larva dan pada perlakuan 8 dengan sebanyak 1 larva yang mati sehingga total 8 larva. Pada konsentrasi $10 \%$ semua larva tidak ada yang mati. Pada konsentrasi $15 \%$ terdapat 1 larva mati pada perlakuan 3 dan 16 larva pada perlakuan 4 total 17 larva. 
Tabel. 1

Distribusi Frekuensi Jumlah Kematian Larva Aedes aegypti Instar III dengan Abate pada Konsentrasi $5 \%$

\begin{tabular}{llllllllllllc} 
& & \multicolumn{1}{c}{ Kematian Larva setiap Pengulangan } & & \multicolumn{2}{c}{ Rata-rata } & $\%$ \\
\cline { 3 - 10 } & Konsentrasi & 1 & 2 & 3 & 4 & 5 & 6 & 7 & 8 & & Kematian & 0 \\
2 & $5 \%$ & 0 & 0 & 0 & 0 & 0 & 0 & 0 & 0 & 0 & 0 & 0 \\
3 & $10 \%$ & 20 & 20 & 20 & 20 & 20 & 20 & 20 & 20 & 20 & 20 & $100 \%$ \\
& $15 \%$ & 20 & 20 & 20 & 20 & 20 & 20 & 20 & 20 & 20 & 20 & $100 \%$
\end{tabular}

Kntrol 20

Sumber : Penelitian Laboratorium

Tabel. 2 pengujian terhadap larva Aedes aegypti menggunakan Abate didapatkan pada konsentrasi 5\% tidak ada larva yang mati, pada konsentrasi $10 \%$ terdapat 160

\section{PEMBAHASAN}

Hasil penelitian pada tabel. 1 dan 2 diatas menunjukkan pada pengujian menggunakan ekstrak daun sirih jumlah kematian larva adalah 8 yaitu pada konsentrasi 5\% dan 17 larva pada konsentrasi $15 \%$, sementara pengujian menggunakan abate pada konsentrasi 10 dan $15 \%$ semua larva nyamuk mati (100\%). Hasil penelitian ini ditemukan bahwa larva Aedes aegypti ditiap wadah larva atau jentik menjadi susah bergerak kepermukaan wadah, ada juga yang menjadi kaku, dan tidak bergerak sama sekali walau disentuh dengan lidi. Pengamatan yang lakukan selama 45 menit dengan konsentrasi $10 \%$ dan $15 \%$ abate dapat membunuh jentik nyamuk sebanyak 100\%. Sejalan dengan hasil penelitian sebelumnya yang dilakukan selama 24 jam menunjukkan bahwa rata-rata kematian larva Aedes aegypti setelah kontak dengan abate adalah 25 (1001\%). Hasil penelitian terbukti bahwa abate efektif dalam membunuh larva, karena

larva yang mati (semua larva mati) sala halnya dengan konsentrasi $15 \%$ semua larva ditemukan mati.

bahan aktif yang terkandung dalam abate yaitu temephos mempunyai daya bunuh yang lebih tinggi dibandingkan kandungan bahan aktif pada larvasida alami. Cara kerja abate pada larva adalah menghambat enzim cholinesterase, sehingga menimbulkan gangguan pada aktivitas syaraf karena tertimbunnya acetylcholine pada ujung syaraf. Fungsi dari enzim cholinesterase aalah menghidrolisa acetylcholine menjadi choline dan asam cuka, sehingga bila enzim tersebut dihambar maka hidrolisa acetylcholine tidak terjadi sehingga otot akan tetap berkontraksi dalam waktu lama maka akan terjadi kekejangan yang berujung pada kematian larva. (Perumalsam dalam Prastha, 2015)

Kematian larva Aedes aegypti
menggunakan ekstrak daun sirih
menunjukkan bahwa kematian larva terjadi
hanya dalam jumlah yang lebih lebih sedikit
dibandingkan menggunakan abate. Senyawa
yang ada pada larvasida nabati mempunyai


sifat racun yang bekerja seperti racun kontak yang dapat memberikan kematian, karena kehilangan cairan secara terus menerus sehingga larva akhirnya menimbulkan kematian. (Dwi Nugroho, 2013). Kandungan bahan aktif ekstrak daun sirih ini memiliki dayabakteri, antioksidasi dan fungisida serta berperan sebagai larvasida, penolak serangga dengan cara kerja sebagai racun kontak dan racun perut. (Fahmi, 2006). Penggunaan insektisida alami akan lebih baik mengingat dampak akibat penggunaan insektisida sintetis menimbulkan kerugian seperti resistensi hama dan terbunuhnya hama yang tidak merugikan. Hal ini dikarenakan insektisida alami bersifat mudah terurai di alam (biodegradable), sehingga tidak mencemari lingkungan dan relatif aman bagi manusia dan hewan, karena residunya mudah hilang. (Wahyuningsih, 2008)

Alternatif pengganti insektisida kimia sintetik, maka dilakukan upaya dengan menggunakan insektisida nabati yang bersifat ramah lingkungan. Insektisida ini berasal dari tumbuhan sehingga memiliki tingkat keamanan yang lebih tinggi, yaitu karena sifatnya yang mudah terurai di alam sehingga tidak menimbulkan bahaya residu yang berat dan lebih efektif, serta tidak merugikan makhluk hidup dan lingkungan yang bukan sasaran. Secara umum, insektisida nabati (hayati) diartikan sebagai sesuatu pestisida yang bahan dasarnya berasal dari tumbuhan. Insektisida nabati relatif mudah dibuat dengan kemampuan dan pengetahuan terbatas, oleh karena terbuat dari bahan alami/nabati maka jenis pestisida ini bersifat mudah terurai (biodegradable).

Beberapa penelitian ilmiah menyatakan bahwa daun sirih mengandung gula dan tanin. Biasanya daun sirih muda mengandung gula dan minyak atsiri lebih banyak dibandingkan dengan daun sirih tua. Sementara itu, kandungan taninnya relatif sama. Selain itu sirih juga mengandung terpena, flavonoid dan saponin memiliki manfaat yang dapat mengganggu sistem saraf nyamuk dan dapat menyebabkan kematian pada larva. (Depkes RI, 2004)

Senyawa lain yang dapat mengakibatkan kematian pada larva adalah steroid dan tannin. Steroid dapat menghambat proses pergantian kulit pada larva. Tannin dapat mempengaruhi penurunan aktivitas pengikatan protein dan penyerapan makanan disaluran cerna. Berdasarkan mekanisme ini perkembangan larva instar III akan terhambat.

Abate sebagai larvasida sintesis tetap mempunyai efektivitas yang lebih baik dibandingkan dengan larvasida alami ekstrak daun sirih. Pemberian ekstrak daun sirih dapat merubah warna dari air dan aromanya pun berubah, hal ini tidak sesuai dengan kriteria salah satu dari kriteria larvasida, yaitu tidak menyebabkan perubahan rasa, warna, dan bau pada air yang mendapatkan perlakuan. Hal ini dimungkinkan karena, dosis ekstrak daun sirih yang diberikan kurang, waktu yang diperlukan untuk membunuh larva tidak secepat abate, sulitnya ekstrak daun sirih (Piper betle) larut dalam 
air, banyaknya faktor pengganggu, dan adanya kesalahan teknis dalam penelitian.

\section{KESIMPULAN}

Esktrak daun sirih yang paling efektif dalam mematikan larva Aedes aegypti adalah $15 \%$ dan dosis abate yang efektif adalah 10\%, 15\%. Berdasarkan hasil penelitian dapat dilihat bahwa abate sebagai larvasida sintetis tetap mempunyai efektifitas yang lebih baik dibandingkan dengan larvasida alami esktrak daun sirih dengan jumlah kematian yang lebih banyak.

\section{SARAN}

1. Bagi Institusi Pendidikan

Diharapkan dapat memperbanyak referensi-referensi penelitian di bidang kesehatan lingkungan khususnya referensi tentang pemanfaatan ekstrak alami sebagai larvasida.

2. Bagi Masyarakat

Masyarakat mampu menerapkan dan melakukan pemberantasan larva Aedes aegypti.

3. Bagi Peneliti

Peneliti dapat dikembangkan dengan menggunakan ekstrak lain dan dapat pula ditambahkan dengan kontrol positif yaitu dengan abate dan kontrol negatif berupa etanol $96 \%$.

\section{DAFTAR PUSTAKA}

1. Depkes RI, 2004. Perilaku Hidup Nyamuk Aedes Aegypti

2. Dwi Nugroho. 2013. Perbedaan Jumlah Kematian Larva Aedes Aegypti setelah Pemberian Abate dibandingkan dengan Serbuk Serai. Diambil Dari Http://Journal.Unnes.Ac.Id/Index.Ph p/Kesmas (30 Juni 2015)

3. Fahmi, Mohammad 2006. Perbandingan Efektifitas Abate dengan Ekstrak Daun Sirih (Piper Betle Linn) dalam Menghambat Pertumbuhan Larva Nyamuk Aedes Aegypti. Semarang: Fakultas Kedokteran Universitas Diponegoro

4. Kardinan, Agus.2007. Pestisida Nabati.Ramuan dan Aplikasi. PT.Penebar Swadya. Bogor. Sel.Vol 1.3 No.1 Juli 2016:31-40.

5. Lidia, Kartini dan E. Widyaningrum.2008. Deteksi Dini Resistensi Nyamuk Aedes Albopictus Terhadap Insektisida Orgonofosfat di Daerah Endemis DBD dDi Palu, Sulawesi Tengah. MKM Vol 03 No 2:1-3.

6. Prastha Indra Ak, Santjaka. Efektivitas Larvasida antara Abate, Ekstrak Daun Sirsak (Annona Muricata Linn) dan Ekstrak Daun Sirih (Piper Betle Linn) terhadap Kematian Larva Aedes Aegypti Instar 3 Tahun 2015. Keslingmas Vol. 34 Hal. 124 - 223 September 2015 | 175

7. Ramayanti. I, Febriani.R. Uji Efektivitas Larvasida Ekstrak Daun Pepaya (Carica Papaya Linn) terhadap Larva Aedes Aegypti, Syifa' Medika, Vol.6 (No.2), Maret 2016

8. Ridha Mr, Nisa K (2015). Larva Aedes Aegypti sudah Toleran 
terhadap Temephos di Kota Banjarbaru, Kalimantan Selatan. Jurnal Vektora, 3 (2): 9-111.

9. Ridha Mr, Nisa K (2015). Larva Aedes Aegypti Sudah Toleran terhadap Temephos di Kota Banjarbaru, Kalimantan Selatan. Jurnal Vektora, 3 (2): 9-111.

10. Wahyuni, M. Perbandingan Efektivitas Pencampuran Ekstrak Daun Sirih (Piper Betle) dan Daun Bengkuang (Pachyrhizus Erosus) dengan Abate terhadap Mortalitas Larva Aedes Aegypti. Jurnal Ilmu Kesehatan Vol. 5 No. 1 Desember 2017.

11. Wahyuningsih, N.E., Dharmana, E., Dkk 2008. Kelimpahan Aedes Spp. di Kota Semarang, Purwokerto Dan Yogyakarta. Jurnal Entomologi Indonesia, 5(1), Pp.45-59

12. Yunita, E, dkk. Pengaruh Ekstrak Daun Teklan (Eupatorium Riparium) terhadap Mortalitas dan Perkembangan Larva Aedes Aegypti. Semarang. UNDIP Press. 2009. Vol.11(1):11-17. 